\title{
Diaspora Kavramı ve Türkiye'nin Diaspora Politikalarının Modern Teori Çerçevesinde Sosyo-Politik Bir Analizi
}

\author{
Ergin Ulusoy
}

\begin{abstract}
Öz: Diaspora çağımızın en önemli toplumsal ve siyasi olgularından biridir. Diaspora teorisi kendi içerisinde klasik ve modern olmak üzere iki ayrı yaklaşım altında ele alınmaktadır. Bu noktada çalışmamız her iki yaklaşımı da değerlendirmekle birlikte açıklamalarında modern yaklaşımları çerçeve edinmiştir. Modern yaklaşımlar küreselleşme, ulus-aşırılaşma ve liberal demokrasi bağlamında bireye ve bireyci bir kolektiviteye odaklanmaktadır. Diaspora olgusu Türkiye'de son yıllarda giderek daha ön plana çıkmasına karşın, bir çalışma ve ilgi alanı olarak bilimsel yönü ihmal edilmiştir. Türkiye'nin devlet politikalarına bakıldığında da aynı ihmalkârlık göze çarpmaktadır. Türkiye, diasporaya yönelik plan ve programlarını sahada gözlemlenen gereksinimlere, farklı baskı gruplarının yönlendirmelerine ve hepsinden de çok siyasi-kültürel belirlenimlerine göre şekillendirmektedir. Bu bakımdan Türkiye'nin diaspora politikalarının tarihsel görünümünde Kemalist, militarist, merkezîyetçi, ötekileştirici bir algının hâkim olduğu görülmektedir. Çalışmamız bu kapsamda diasporanın öncelikle teorik açımlamasını yapmakta, akabinde ise Türkiye'nin diaspora politikalarının altında yatan tarihsel belirlenimleri modern yaklaşımlar bağlamında ve siyasi-sosyolojik bir çerçeve içerisinde analiz etmektedir. Yazının kapsamı, diaspora teorileri, küreselleşme, ulus-devlet, ulus-aşırılaşma, vatandaşlık, entegrasyon ve Türkiye'nin siyasi-toplumsal tarihi olarak belirlenmiştir.
\end{abstract}

Anahtar kelimeler: Göç, Diaspora, Modern Diaspora, Klasik Diaspora, Türk Diasporası, Yurtdışı Türkler.

\begin{abstract}
Diaspora is one of the most important social and political events of our time. Diaspora theory is considered within two different approaches, classical and modern. Our work at this point has taken both approaches into account, as well as modern approaches in their explanations. Modern approaches focus on individual and individualistic collectivism in the context of globalization, nation-default and liberal democracy. Although the phenomenon of diaspora has become more and more prevalent in Turkey in recent years, the scientific aspect has been neglected as a study and interest. When we look at the state policies of Turkey, the same negligence is striking. Turkey shapes its plans and programs for diaspora according to the observed requirements, the conveys of different pressure groups, and the very political-cultural determinations of all. In this respect, it seems that Kemalist, militarist, centralist, and otherizing perception are dominant in the historical view of Turkey's diaspora policies. In this context, our work primarily explains the theoretical explanations of the diaspora, and then analyzes the historical determinations underlying Turkey's diasporic policies in the context of modern approaches and within a political-sociological framework. The scope of the article is defined as diaspora theories, globalization, nation-state, nationalism, citizenship, integration and Turkey's political-social history.
\end{abstract}

Keywords: Migration, Diaspora, Modern Diaspora, Classic Diaspora, Turkish Diaspora, Turkish Abroad.

(C) İlmi Etüdler Derneği

DOI: 10.12658/human.society.7.13.M0167

İnsan \& Toplum, 7(1), 2017, 139-160.

insanvetoplum.org
Haşvuru: 02.01.2017

Revizyon: 22.02.2017

Kabul: 09.05.2017

Basım: 30.06.2017 


\section{Giriş}

Diaspora, göçün içerisinde bulunduğumuz zaman ve şartlar dâhilinde yerleşikleşmek, toplumsallaşmak, politikleşmek, kök salmak hedef ve arzuları ile nihayete erdiği nokta olarak belirginleşmektedir. Bu nedenle diasporizasyon ulus-aşırı çağda modernizmin toplum modelini demokratikleştiren, insancıllaştıran ve çağcıllaşt1ran bir olgu olarak ortaya çımaktadır. Dolayısıyla diaspora, demokrasi ve insan hakları bağlamında ortaya çıkan yeni toplumsal biçimlerden biridir. Ya da daha politik bir bakış açısıyla modern ulus-devletlerin egemenlik alanındaki bir kırılma, "toplumsal çöp" olarak nitelenen gettoların öz-farkındalık kazanarak denklik aradıkları bir demokratik toplumsal mücadele aracıdır.

Bununla birlikte diasporalarda da pek çok alanda olduğu gibi tek bir okuma, egemen bir zihniyet söz konusu değildir. Bu bağlamda diaspora çalışmaları, iki farklı ön kabul üzerinden yürümektedir. Bunlardan ilki diasporayı en eski bağlamları içerisinde kabul eden ve yorumlayan klasik (etnografik) yaklaşım, diğeri ise özellikle 1980'lerle birlikte ortaya çlkan ve daha çok modern göçlerin küreselleşme, ulus-aş1rılaşma ve post-modernizm ile olan etkileşimleri dolayımında incelendiği, modern yaklaşımdır. Öte yandan modern diasporaların varlığı ve gelişimi liberal demokrasiler ve serbest pazar içerisinde hayat bulabileceğinden, daha çok Batı tipi demokratik sistemlere sahip ülkelerde görülmektedirler. Bu noktada bir baskı grubu olarak hareket eden diasporalar, zamanımızın en vazgeçilmez sivil toplum ögelerinden biri haline gelmiştir. Ancak bu noktada köken ülkenin diaspora üzerinde tahakküm kurmaması veya bir angajman yaratmaması son derece önemlidir. Zira diasporayı kontrol altında tutmak veya klasik bağlamlara hapsetmek, diasporaya büyük zararlar verecektir. Bu bağlamda diasporalar, zaman içerisinde, mesken ülke ${ }^{1}$ toplumunun ayrıştırıcı, izole edici kültüralist davranışları ve politikaları hayata geçirmesine, sosyal-liberal anlayışların eriyerek siyasal ve toplumsal alanlara muhafazakâr eğilimlerin hâkim olmasına etki eden bir katalizör haline gelecektir. Sonuçta hem diaspora hem köken ülke hem de topyekûn bir şekilde yabancilar, mesken ülke toplumu ve devleti için aranan antagonizmayı oluşturarak zihinsel bir sabite hapsedileceklerdir.

Türkiye ile diasporası arasında yukarıda açıklananlar kabilinden bir takım problemler yaşanmaktadır. Yeni Cumhuriyetin ortaya çıkışında kurucu ideoloji ve

1 Mesken ülke kavramı, yabancı metinlerde geçen 'host country' ifadesine karşılık olarak üretilen yaşanılan ülke, yerleşilen ülke, ikamet edilen ülke gibi uzun ve her biri farklı bir anlama vurgu yapan karşılıkların yerine ilk kez anılan doktora çalışmasında kullanılmıştır. Böylece İngilizcedeki host country kavramının eşdeğerlik arz eden bir kelime ile karşılanması, root-host country ikilisinin köken-mesken ülke şeklinde pratik ve doğru bir yapıya kavuşturulması amaçlanmıştır. 
yapısal çerçeve olarak ortaya konan Kemalizme dayalı merkezîyetçi devlet anlayışı, toplumumsal yapıyı ve buna bağlı olan ekonomik, kültürel ilişkileri biçimlendirme ereği göstermiştir. Bu bağlamda Türkiye'nin uzaktaki bir parçası biçiminde konumlanmış olan Kemalist devlet politikaları ile Türk Diasporası arasında da devletin insanı biçimlendirdiği bir etkileşimden söz edilebilir. Bu anlamda diasporanın özellikle oluşumuna yani göç süreçlerine odaklanıldığında biçimlendirici ve yönlendirici ideoloji ve yapı daha iyi görülebilmektedir (II. Beş Yıllık Kalkınma Planı; Görmezöz, 2011; Gür, 2012; Zürcher, 2010; Şenay, 2012; Güngör, 2005; Artuklu, 2005; Kofralı vd., 2010; İçduygu, 2006-2014; Tanör vd., 2005; Cumhuriyet Gazetesi, 2013; Turkishnews, 2008). Bu durum, iki yönlü, yani hem merkezden diasporaya hem de diasporadan merkeze doğru bir bozulmayı gündeme getirmektedir. Türkiye'nin diasporası ile yaşadığı ve onlara yaşattığı en büyük sıkıntıların, öncelikle yaşadığ1 demokrasi sorunlarına ve modernizme içkin varoluşsal eksikliklerine dayandığı söylenebilir. Bu anlamda Türkiye'nin diasporası ile arasındaki etkileşim bir dizi tarihsel gelişmenin günümüze yansıyan sonuçlarıyla doğrudan ilgilidir.

Çalışmamız bu kapsamda diasporanın tanımı ve tasnifleri üzerinde durmakta, Türkiye'deki bilimsel araştırmalar açısından yabancı bir kavram olan modern diaspora kavramına eğilmekte, modern diasporanın ne'liğine ve nasıl'lığına ilişkin bir açıklama getirmektedir. Bununla birlikte çalışma göç disiplinin bakış açısını aşan, diaspora disiplinine ilişkin Türkiye'deki ilk spesifik çalışma olması bakımından özellikle Türkiye'nin politikaları tartışmasında önceki kaynakları kullanan bir derlemeden ziyade; kaynak teşkil etme ümidindeki yüzlerce sayfalık bir tez çalışmasının birkaç bin kelimelik özeti niteliğindedir. Bu bakımdan diasporanın teorik açıklanışını takip eden bölümlerde bir öngörü oluşturabilmek maksadıyla daha ziyade ilk kez tartışılan fikirlere ve içeriklere yer verilmiştir.

\section{Diasporanın Kavramsal Boyutu ve Klasik ve Modern Diaspora Yaklaşımları}

Diaspora sözlük itibarıyla; herhangi bir ulusun veya inanç mensuplarının ana yurtları dışında azınlık olarak yaşadıkları yer; herhangi bir ulusun yurdundan ayrılmış kolu demektir. Etimolojik kökenlerine inildiğinde ise kullanımını eski Yunan'a kadar götürmek mümkündür. Yunanca 'ile' ya da 'sonucunda' anlamina gelen "dia” kelimesiyle 'dağılma' anlamına gelen "speiro” sözcüklerinin bir araya gelmesiyle oluşan kavram, Antik Yunan'da, "bir anakentten (metropolis) çıkan insanların göç veya kolonizasyonunu tarif etmek için kullanılmıştır" (Cohen, 1997, s. ix). "Çok kısa bir zaman öncesine kadar, çok geniş Ermeni, Yunan ve Afrika diasporaları kayıtlarının bulunmasına rağmen, bu kavram daha çok Yahudilerin sürgün son- 
rası dağılmalarını ifade etmek için kullanılıyordu” (Butler, 2001, s. 190-192). Öte yandan speiro sözcügünden gelen "sperm” kelimesinin Yunanca kökeniyle kurulan ilişki diasporanın cinsiyet-özellikli ve maskülen olarak tanımlandığı problematik tanımlar/tespitlere yol açmıştır. Diasporayı etnisite ile eşitleyen diğerleri, diasporanın maskülen-özellikli bir kavram olduğunu iddia ederler” (Alinia, 2007, s. 32).

Diaspora disiplini içerisinde iki temel yaklaşım bulunmaktadır. Bunlardan ilki klasik yaklaşım, ikincisi ise modern yaklaşımdır. Klasik yaklaşımlar daha ziyade Yahudi, Ermeni, Afrika, Filistin diasporası gibi göçe bir zorunluluğun sebep olduğu, daha kapalı nitelikte, anavatan miti ve dinsel-kültürel ögeler etrafında örülen kalın duvarlı bir yapıyı işaret etmektedirler. Michele Reis’in International Migration Journal (Uluslararası Göç Dergisi)'da yayımlanan makalesinde de belirttiği üzere; klasik diaspora yaklaşımları Yahudi Diasporası'nın tarihsel deneyimini başlangıç noktası olarak almaktadırlar. Bu yaklaşım çerçevesinde şekillenen diaspora kavramı, sentrik bir yaklaşımın anlamını kuvvetlendirme amacı taşıyan kimlik unsurlarından biridir. Bu bağlamda "diaspora, eski kavranışları doğrultusunda, diaspora ile diğer gruplar arasındaki bazı kültürel farklılıkları ima etmektedir" (Beck'ten akt. Faist, 2010, s. 15). Yine bu doğrultuda diasporanın “...eski kavranışları, üyelerinin sosyal açıdan (politik, ekonomik, kültürel açılardan) mesken ülkelerine tam olarak entegre olmadığını, çoğunluk gruplarıyla aralarına sınırlar koyduklarını ve o sınırları koruduklarını ima etmektedir. Diasporanın bu kavranışı sıklıkla baskın bir çoğunluğun diaspora gruplarına karşı uyguladığı ayrımcılığa ilişkin bir sınır muhafazası ile alakalıdır" (Bhabha'dan akt. Faist, 2010, s. 13). Aklımızda veya hayalimizde iz eden mekânsal kökeni (mekân bağlantılı olarak var olan her şey) göç sürecinde beraberimizde taşımak mümkün olmadığından, bu yeri tüm 'ruhu' ile birlikte mesken ülkedeki diasporaya taşımak ve ağların ve yapıların birbirleri ile bağlantılı hale gelmesini sağlamak için ortak hafıza ve değerleri cisimleştirip hayata dâhil edebilecek nesnelleştirmeler bulmak gereklidir. Böylece hem diasporanın kimlik ekseninde şekillenen varlığı kuşaklar arası aktarım yoluyla yaşama imkânı bulabilecek hem de fiziksel ve zihinsel açıdan köklerinden uzak veya mobilize olmayan bireyler, diaspora çatısı altında diğerleriyle buluşup birleşebileceklerdir. Amacın başarıya ulaşabilmesi, soyutlaştırılan kökene ilişkin hafıza ve değerlerin sembolleştirilmesi, seremonileştirilmesi ve gelenekleştirilmesi ile mümkündür.

$\mathrm{Bu}$ sayede diasporik siyaset, gerek kökenle ve diğer diasporik yerleşim alanlarıyla kurulan her türden aşkın bağlantılar gerekse de ağ içerisinde yer alan herhangi bir unsurun doğrudan veya dolaylı olarak yaratacağı nicel veya nitel etkiler nedeniyle, algı ve davranışlar üzerinden ulus-aşırı siyasi alan içerisinde resmedilebilecektir. Böylece Michelle Laguere'in (2006) de belirttiği üzere; 
"diasporik siyaset çalışmaları bizi, diasporik siyasetin ulus devlet siyasetinin görünürdeki karakterine eklediği hareketlilikten dolayı yalnızca ulus kavramının varoluşsallaştırılmasına (deessentialize) veya yeniden ele alınmasına değil, aynı zamanda bunu diasporanın kavranışı konusuna da uygulamamız için zorlayarak diaspora ve ulus-aşırıcılığın, sosyal bilimlerin cemaat, toplumsal alan, bağlılık gibi temel kavramlarını sorgulamak ve yeniden tanılamak için önemli birer unsur haline gelmesini" (s. 163) sağlar.

Bu nedenledir ki, "ulus-aşırı veya diasporik bir bakış açısının, ulus-aşırı toplumsal alanlar gibi kendine özgü, emsalsiz toplumsal formasyonlar ve sınır-ötesi hareketler sürecinde yeni anlamlar kazanan vatandaşlik veya yerel politikalar gibi eski yerel ulusal ve uluslararası kurumların tümüyle mücadele edebilmesi gerekir" (Faist, 2010, s. 33-34).

Modern yaklaşımlar ise diaspora çalışmalarını herhangi bir kültürel merkezciliğin veya Yahudi Diasporası gibi örnek diasporaların dominantlı̆̆ında incelemek fikrine karşıdır. Modern diasporalarda öncelikle birey olarak var olan diasporanlar, mesken ülke toplumu içerisinde tutunabilmek ve ona katılabilmek için mücadele eder; toplum içerisindeki konumlarını ve toplumla olan bağlamlarını evrensel normlar ve insan hakları üzerinden kurarak hareket ederler. Bu anlamda "diasporanın yeni kavranışları ulus-aşırı boyutlu bir yayılım içerisinde kültürel melezleşmeye vurgu yapmaktadır." (Bhabha'dan aktaran Faist, 2010, s. 13) Dolayısıyla kavramin süreç içerisinde kazandığ1 yeni anlam, küreselleşmenin giderek görünürlük kazanmasına ve ulus devletin zayıflamasına paralel olarak, her türden göç ve dağılmanın sonuçlarıyla ilişkili hale gelmiştir. Bu noktada diasporanın kazandığı yeni anlam ve gelişim konusunda endişeli olan Tötölyan'ın (2012) şu ifadeleri dikkate değerdir:

"Diaspora kavramının semantik alanı; göçmen, gurbetçi, mülteci, misafir işçi, sürgün, deniz aşırı topluluk ve etnik cemaat terimleriyle paylaşılmaya başlandı ve diasporalar ulus-aşırı alanların örnek toplulukları haline geldiler. Burada kastettiğim; ulusa dayalı olanlar gibisinden eski diasporalar yeniden şekillendirilirken, yenilerinin ise sinır aşan bilgi, fikir, imajlar ve müzik kadar insanlar, para ve kültür ürünlerinin de hızlandırılmış mobilizasyonu tarafindan yeniden oluşturulduğudur." (s. 55)

Bu anlamda Tötölyan'ın yazılarından anlaşıldığına göre, diasporaların ortaya çıkışı ve politizasyonu değişmelere koşut biçimde pek çok etmene bağlıdır ve artık en etno-sentrik ve kapalı diasporalar dahi modern yaklaşımların tanımlamalarından ve yöntemlerinden etkilenmeye başlamışlardır. Kaldı ki günümüzde diaspora kavramı, mekânsal anlamda bir vatanla ilişkilendirilmesi zorunlu olmayan, bu nedenle de Yahudi örneğindeki gibi geri dönüş hayali ve hatta ideolojisi geliştirmek zorunda olmayan bir olguya işaret etmektedir. Bununla birlikte yine Michelle Reis'ın (2004, s. 47) bilhassa belirttiği gibi, modern yaklaşımlar çerçevesinde diasporalar illa bir kriz veya travmatik bir olay sonucu ortaya çıkmak zorunda da değildir. Özellikle kü- 
reselleşme bağlamında bakıldığında, göçler bugün artık yalnızca travmatik bir olaya veya bir felakete bağlı olarak meydana gelmemektedir. Değişen koşullarla birlikte yer değiştirmelerin koşullarında da değişmeler olmakta ve bu durum 'fırsat kollayan' yeni diaspora örneklerini yaratmaktadır. Küreselleşme süreci ile yaygınlaşan ve kolaylaşan iş takipleri ve küresel iş fırsatları, emekli göçleri, öne çlkan eğitim fırsatları ve insanların birbirleri ile olan etkileşimlerini hızlandırıp, yoğunlaştıran her türden yurt dışı seyahatler, modern diaspora süreçlerinin canlandırılmasında etkili olmuştur. Söz ettiğimiz bu değişim kaçınılmaz bir durumdur zira günümüz diasporaları artık yalnızca yoğun bir politik ve/veya kültürel çatışmaya bağlı olarak değil, aynı zamanda küreselleşmenin tetiklediği 'fırsatlara' da bağlı olarak şekillenmektedir. Dolayısıyla günümüzde artık diaspora, her alanda hızla gelişen bir olgu olarak hem siyasi hem de toplumsal açıdan görünürlük kazanmaktadır.

Nihayetinde diasporanın kazandığı yeni anlam Georgiou'nun ifade ettiği gibi:

\footnotetext{
"Diaspora... kan bağlarıyla belirlenen istikrarlı oluşumlar değil, dağınık nüfuslar ve/ veya memleketler boyunca gerçek ve hayali bağlantıları devam ettiren merkezî olmayan kültürel oluşumlardır. Yeniden kavramsallaştırılmış haliyle diasporalar; kutsal, kabile toplumuna ait bir anavatanın arayışında olan bozulmamış, zorla ya da mecburiyetten yurdundan uzaklaştırılmış/dağılmış insanların amaç birliğinden ziyade farklı, karma ve heterojen kimlikleri barındıran geçirgen ve sürekli dönüşen sosyal ve kültürel oluşumlar olarak anlaşılır." (Georgiou'dan akt. Ataman, 2012, s. 53)
}

Diasporanın bu yeni anlamında gönüllülük, bilinç ve organizasyonun kazandığı önem, onu giderek daha siyasi ve pragmatik bir zemine çekmiştir. Bu anlamıyla diaspora; hâkim unsurların bilinçli veya bilinçsiz, sistemli veya kendiliğinden gelişen şekilde uyguladıkları ötekileştirme, uzaklaştırma, yalıtma ve asimilasyona varoluşsal bir cevap niteliği taşımaktadır. Diasporada yaşayan göçmenler, mesken ülkede kalıcı olmak, orada yaşamak ve kök salmak, mesken ülkenin toplumuna ve yaşantısına entegre olmak iradesindedirler. Ancak söz konusu entegrasyon vizyonu, asimilasyona karşı ve onunla mücadele eden bir çerçevede gelişir. Diaspora içerisinde bir araya gelen göçmenler (gevşek veya sıkı) bir yapı kurmakta, sosyal, siyasal ve ekonomik bir mücadele vermektedirler. Söz konusu eylemsellik ve durumsal değişiklik, zaman içerisinde yaşadıkları ülkenin daha demokratikleşmesine ve küresel anlamda uygarlaşmasına destek veren bir takım siyasal-kültürel etkiler de doğurmaktadır ki bu, diyalojik bir demokrasiyi yaşatabilmek misyonunun başarıya ulaşabilmesi açısından oldukça önemlidir. Böylece kurumsallaşmış kimliği ve farklılıklarla birlik sloganı ile amaç ve vizyonunu görünürleştiren diaspora, siyasetin yalnızca nesnesi değil, aynı zamanda öznesi de olabilmektedir. 


\section{Türkiye'nin Diaspora Politikalarının Modern Yaklaşımlar Bağlamında Analizi}

Türkiye'nin, diaspora konusunda farkındalığının oluşması ve harekete geçmeye başlaması, diasporanın göçten farklı bir disiplin ve konu olduğu dikkate alındığında aslında çok da uzun değildir. Türkiye, bir önceki bölümde de görüldüğü şekilde konuya özellikle 2000’lere değin alışageldiği gibi bir göç ve göçmenlik meselesi olarak yaklaşmıştır. Ancak, yurtdışında yaşayan insanlarımızın mesken ülke toplum yapısı ve ekonomisi içerisinde sınıfsal-statüsel bakımlardan gelişme kat etmeye başlamaları üzerine, yurt-dışı Türkler olgusunda göçmenlikten diasporalaşmaya doğru bir bükülme yaşanmaya başlamıştır. Böylece Türkiye de yaşanan değişime tepki vermiş, oluşmaya başlayan yeni durum çerçevesinde politikalarını revize etmek yönünde açık bir niyet ortaya koymuştur.

$\mathrm{Bu}$, yurt dışındaki insanlarımızın bundan önceki dönemlerde nasıl bir muamele gördükleri ve ne şekilde değerlendirildikleri düşünüldüğünde oldukça önemli bir adım olarak nitelendirilebilir. Ancak ne var ki, açıkladığımız üzere, diaspora ve göç iki ayrı alan, yöntemleri, düşünme biçimleri, kapsamları, etkileri, sebepleri ve sonuçları farklı iki ayrı disiplindir.

$\mathrm{Bu}$ doğrultuda mevcut diaspora politikamızın göç politikası kalıplarımızın uzantısı olarak devam eden, üçü Erdoğan'ın açıkladığı, ikisi çalışmayla ortaya konan toplam beş temel alan üzerinde yükseldiği söylenebilir. Klasik politikalarımızın devamı olan bu beş alandan "ilki eğitim alanıdır, diğeri din alanıdır, üçüncüsü de çalışma alanıdır," (Erdoğan, 2012, s. 2) dördüncüsü ekonomi alanı ve beşincisi ise STK'lar alanıdır. Eğitim alanındaki örgütlenmemiz yurtdışına gönderilen öğretmenler ve bu öğretmenleri koordine edecek eğitim ataşeleri kapsamında ortaya çıkmıştır. Yurtdışında Türkçe'nin öğretilmesi için mesken ülkece sağlanan boş saatlerde eğitim veya seçmeli ders benzeri yöntemlerle Türkiye kökenli çocuklara dil eğitimi verilmesi amacıyla yurtdışına öğretmenler gönderilmiştir. Bu öğretmenler Türkçe'nin yanısıra Türkiye'nin kültürünü, tarihini öğretme görevi de üstlenmişleridir. Bunun hemen akabinde gönderilen öğretmenlerin koordinasyonlarının ve faydalarının artması, eğitime ilişkin sorunların çözümü gibi amaçlarla eğitim ataşeleri görevlendirilmiştir. Bu kapsamda eğitim-öğretim hizmetlerinin amacının kültür, dil ve tarih bilgisinin korunumu ve aktarımı, Türkiye'ye bağlllığın ve desteğin korunumu ve aktarımı, Türkiye kökenli toplumun asimilasyonunun önlenmesi ve otantikliğin korunması olduğu ifade edilebilir. Diaspora politikamızda ikinci ayak ise din ataşeleridir. Din ataşelerinin görevleri, yurt dışındaki insanlarımızın dinî gereksinimlerini karşılamak olarak ortaya konmuştur. Öte yandan amaçlara odaklanıldığında ise yurt dışındaki insanlarımızın göçmenlik kültürü içerisinde içine kapandığı bir or- 
tamda Türkiye ile bağlarını korumak, dinî ve kültürel bütünlüklerini ayakta tutmak ve aslında bir bakıma asimile olmalarını önlemek amacıyla yola çıkıldığı görülmektedir. Diaspora politikamızın bir diğer ayağını ise çalışma ataşeleri oluşturmaktadır. Çalışma ataşeliklerimiz, insanlarımızın iş yaşamında karşılaştıkları fizikî, sosyal ve hukukî koşulların iyileştirilmesi, karşılaşılan sıkıntıların aşılması noktasında destek vermektedir. Göç politikalarımızın uzantısı olarak diaspora politikalarımıza sirayet eden diğer iki önemli ayak ise ekonomi ve STK'lar ayağıdır. Bunlardan ekonomi söz konusu olduğunda yurt dişında yaşayan Türkiye kökenli girişimcilerle geliştirdiği ilişkiler ön plana çıkmaktadır. Göç ile eş-anlı olarak ortaya çıkan ve gelişen ekonomi politikalarımızın temel seyri, tarihsel izlek altında anlattığımız biçimde tek taraflı bir aktarım ve hatta sömürü düzeni biçiminde gelişmiş ve anavatanın diaspora üzerinde otoritesi söz konusu olmuştur. Diaspora kavramı gündeme geldikten sonra ise, AK Parti ile söz konusu tek taraflılık nispeten kırılmış fakat bu kez de eski hasletler olan ekonominin ve iç siyasetin finansmanına bir de yurtdışı yönelimli lobicilik hedeflerinin eklenmesi, ekonomi ayağının kapsamını ve çapını genişletmiştir. Bunlara ilaveten, yine salt ekonomik bağlamda, yurtdışındaki girişimcilerimizin devlet olarak Türkiye ve Türkiye'deki işadamı, sanayi, ticaret örgütlenmeleri ile olumlu ilişkiler geliştirmeleri, dünyanın ekonomik kriz yaşadığı bir dönemde mesken ülke-köken ülke atımlı ticarete olumlu katkı yaparak üretim ve kârlılığa etki etmekte, onların önemlerini ve değerlerini hem içeriden hem dışarıdan artırmaktadır. Ekonomik ayağın ardından gelen son alan ise, STK'lar ayağıdır. STK'lar, göç politikalarımız içerisinde de önemli yeri olan ve fakat diaspora ile yıldızı iyice parlayan bir konudur. STK'ları diaspora politikamızın temel alanlarından biri yapan şey; STK'lara yönelik olarak başlatılan 'görünür ve yoğun' faaliyetlerdir.

Devletin diaspora politikasını biçimlendirirken benimsediği beş temel nokta bu şekildedir. Ancak bu noktaların açıklanması, devletin yurtdışı Türklerle diaspora politikaları bağlamındaki etkileşimini ve politikaların nasıl belirlendiğini anlamak açısından yeterli değildir. Dolayısıyla bu noktada diaspora politikamızın daha derinliklerine inmek ve onu şekillendiren saikleri gün yüzüne çıkartarak pratiği teorik bağlamla irtibatlandırmak, yurt dışındaki Türkiye kökenlilerin diasporalaşmalarına ve devletin politikalarına dair diğer belirleyenlere de değinmek gerekmektedir.

Türkiye'de diasporaya yönelik politikalar iki ana yaklaşımın etkisi altındadır. İlki, devletçi ve tözcü geleneğin klasik yaklaşımları, ikincisi ise ekonomik aktörlerin gündeme getirdiği lobicilik yaklaşımıdır. İlkinde Türkiye devlet olarak diasporaya kendi merkezîyetçi-Kemalist tarihsel-toplumsal okumaları üzerinden yaklaşmakta, buna göre bir yapılanma ve davranış tarzı belirlemektedir. Bu, Türkiye'nin ilk izleri kuruluş safhasında da görülebilecek olan ve temelde demokrasi sorunsalı 
çerçevesinde irdelenmesi gereken bir yaklaşım yaratmaktadır. İkincisi ise serbest pazar içerisindeki ekonomik aktörler sivil toplumun kalanından daha etkili olduğu için devletin kanalize edilmeye çalışıldığı bir anlayıştır. Buna göre ekonomik aktörler lobicilik bağlamında ele aldıkları diasporik etkileşimleri, diasporanın tanımlayıcı çerçevesine indirgeyerek, oldukça pragmatik yer yer hatta oportünist bir alan yaratmaktadırlar. Bu yaklaşım içerisinde diasporanın toplumsal ve kültürel gelişim süreçlerinin özgünlüğü ikinci plana itilmekte ve diasporizasyon aktif olarak şekillendirilmeye çalışmaktadır.

Bunlara ilaveten Türkiye'nin devlet olarak her şeyden önce diaspora politikaları oluşturmak için herhangi bir kılavuzunun bulunmuyor olması, en temel bir sorun noktasını teşkil etmektedir. Türkiye'nin diasporasına yönelik olarak oluşturduğu veya görev tanımının kapsamı dolayısıyla sorumluluk verdiği tüm kurum, kuruluş ve kişiler plan ve faaliyetlerinde deneyimleyerek farkına vardıkları sorunlar ve tarihsel önyargilar üzerinden hareket etmektedir. Tabii bu noktada Türkiye'nin diasporası ile yaşadığ1 ve onlara yaşattığı en büyük sıkıntıların, öncelikle yaşadığı demokrasi sorunlarına, Kemalist-militarist-otoriter devlet yapısına, militaristleşmiş toplumsal zihniyetine ve kuruluş aşamasına dayanan modernizme içkin varoluşsal eksikliklerine dayandığı söylenebilir.

\footnotetext{
"Osmanlı döneminde temelleri atılan modernleşme, Batı'dakinin aksine, ekonomik gelişmelerden değil, siyasi gelişmelerden kaynaklanmıştır. Üstelik yine Batı'dakinin aksine Türkiye'deki modernleşme aşağıdan yukarıya doğru, yani toplumsal alandan siyasi alana doğru değil, merkez olan siyasi alandan çevre olan toplumsal alana doğru inşa edilmiştir." (Kahraman'dan akt. Baştürk, 2008, s. 57)
}

Türkiye gibi bir ulus devletin modernizm bağlamındaki inşasının gerekli sınıfsal ve teknolojik dinamiklerini ve somut unsurlarını taşımayan ülkelerde iktidar, merkezdeki güçlerin etkisi ile tepeden yapılandırılmakta ve ortaya otokratik yönetim biçimleri çıkmaktadır. Dolayısıyla Türkiye'de iktidar, çerçevesi ve niteliği taban tarafından belirlenmiş ve yine taban tarafından yapılandırılmış bir araç olmak yerine, tabanın üzerinde konumlanmış, onu tayin ve tanzim eden, merkezîyetçi bir yapı ve amaç olarak ortaya çıkmıştır. Nitekim açıkladığımız belirlenim içerisinde Türkiye'nin kültürünün modernizmin gerekleri doğrultusunda ortaya çıkan militarist bir çerçeve ile sınırlı kalması, Türkiye'nin toplumsal ve kurumsal açıdan tayin ve tanziminin askerî ve bürokratik bir elit-merkez tarafından yapılmasıyla iyiden iyiye kanıksanmıştır. Ki bunun sebebi de, Murat Belge'nin de (2012, s. 149, 156, 164) uzun uzun açıkladığı üzere; Türkiye gibi zamanının III. Dünya Ülkesi konumundaki ülkelerde var olan orta sınıf yoksunluğunun, sahip olduğu toplumsal biçimlendirme ve toplumsal organizasyon yeterliliği nedeni ile askerî bürokratik elit- 
lerle yamanmaya çalışılmasıdır. Dolayısıyla modernizmin zihin haritalarından ve yaşam pratiklerinden uzak olan Türkiye'de devletin sosyal mühendislik düşüncesi ile hareket etmesi, toplumun uyum ve katılım merkezli hiyerarşik önyargıları da dikkate alındığında, (Sarıbay, 2000, s. 48) bazı toplumsal kesimlerinin hızla merkez dışına itilmesini, kaçınılmaz kılmıştır.

Ancak, öte yandan bugün, içerisinde yaşadığımız dönüşüm sonucunda Türkiye'nin de küresel ve bölgesel konjonktür gereği devlet yapısı ve demokrasi anlayışında gerçekleştirmek zorunda olduğu reformlar ve değişimler, diaspora konusunda da hızla uzun mesafeler alınmasını sağlayabilecek fırsatlar doğurmaktadır. Bu bakımdan bilhassa Kürt sorununun halledilmesi; dinî ve mezhepsel azınlıklara talep ettikleri demokratik hakların demokratik toplum anlayışı çerçevesinde verilmesi; siyaseten iktidara muhalif kesimlerin siyasi ve toplumsal alanlarda ötekileştirilmemesi, yeni sterilizasyon politikaları ve antagonistik toplum mühendisliği projelerinden uzak durulması sözü edilen fırsatların somut uygulama alanları olarak belirginleşmektedir. Fakat devletin politika ve uygulamaları eski davranış kalıplarının benimsendiğini göstermektedir. Nitekim AK Parti'nin yurtdışı organizasyon ve faaliyetlerinde muhafazakar bir toplumsal çerçeveyle sinırlı olan ve AK Parti'nin dillendirdiği politik yaklaşımların dağıtıcısı konumundaki Türk Demokratlar Birliği (TDB) buna iyi bir örnektir. AK Parti’nin özellikle dönemin Başbakanı Erdoğan'ın yurtdışı ziyaretlerinde kürsü olarak TDB'ni kullanması, AK Partili vekillerin yurtd1şı ziyaretlerinde TDB ile birlikte hareket etmeleri kutuplaştırıcı bir etki yaratmakta ve kutuplaşmayı sürekli beslemektedir. Oysa bu tür faaliyetler ve çalışmaların altından başarıyla kalkacak ve devlet ve diaspora ilişkilerinde objektif bir duruş sergilenmesine katkı sağlayacak Türkiye Cumhuriyeti Devleti'nin ilgili ülkelerde güçlü yurtdışı temsilcilikleri ya da özel organizasyon şirketleri bulunmaktadır.

Bu anlamda diaspora içerisinde eski merkezlerin hızla çeperlere 'dağıtılırken', çeperlerde yer alan kesimlerin yeni merkez olarak konumlandırılmaya çalışıldığı görülmektedir. Bu durum, iki uç, yani diasporanın yeni merkezi ile Türkiye devleti arasındaki siyasi-ekonomik bağlaşıkların etik ve etik dışı şekillerde giderek artarak, diasporizasyonu, tam da devletin en başından beri arzu ettiği üzere, Türkiye'nin emrindeki bir enstrümana çevirmektedir. Burada devletin stratejisi daha da güçlenmek için yurt dışındaki muhafazakar dünya görüşüne sahip diasporanların desteğini arkasına almak, bu amaçla da yarattığı yeni merkezi güç halesi içerisine çekerek ekonomik ve siyasi bakımdan desteklemektir. Bu elbette AK Parti'ye has bir tutum değildir. Devrim'in kurduğu teritoryal alanı tüm boyutlarıla yeniden düzenlemesinin doğurduğu sancıların, sonraki dönemlerde asker idaresi ile zirve yapan bir ötekileştirme ve sterilizayon halini alması, tabandaki toplumsal kesimlerde biriken tepkinin siyaset içerisinde tarihsel bir 'davaya' dönüşmesine yol açmıştır. 
Türkiye'de ifade ve temsil olanakları kısıtlanan ve bastırılan gruplar için bir tür kurtuluş olan göç ve diaspora, Türkiye'de siyasetin ideolojik zeminini besleyen, ekonomik finansmanını sağlayan bir tür yeni güç olarak belirmiştir. Bu, tabii ki, devletin gözetimi ve izni ölçüsünde gerçekleşmiştir. Zira devlet, içerideki otoritesini ve gücünü koruyabilmek için ancak beslediği kadar güçlü olabilecek bir düşmana ihtiyaç duymuştur. Fakat ne var ki, iktidar rüzgârlarının yön değiştirmesi ile devletin olanaklarına erişim sağlamayı da başaran diasporanın muhafazakâr kesimleri, sahip oldukları potansiyellerini hızla somutlaştırmaya ve iktidar gücünü beslemeye başlamışlardır. Yani bir bakıma diasporanın (özellikle de Avrupa diasporasının) genel niteliği ile örtüşmeye başlamış ve diaspora ile Türkiye arasında simbiyotik bir ilişki biçimi doğmuştur. Lakin iktidarın giderek güçlenmesi ve modernist yönetim biçimlerinin ve ideolojilerin çözülmeye başladığı bir dönemde yeniden antagonistik bir iktidar ve bunun üzerinden gerçekleştirilecek bir toplumsal mühendislik projesine yönelmesi, diaspora için de Türkiye toplumu için de yıkıcı olacaktır. Dolayısıyla Türk diasporasının sağlıklı bir kendinden inşa süreci geçirebilmesi için en önemli gereksinim; devletin normalleşmesi, demokratikleşmenin sağlanması ve diaspora üzerindeki angajmandan vazgeçilmesidir.

Devletin normalleşmesi ve demokratikleşme, devlet ve toplum hafızasına hâkim yargıların değişmesine bağlı olduğundan, bu konudaki ilerlemelerin zaman alacağı açıktır. Ancak, bunun dışında da devlet politikaları odaklı olarak atılabilecek bazı adımlar bulunmaktadır. Çalışmamız içerisindeki son başlıkta uzun uzun açıklamaya çalıştığımız bu adımların özü; destekleyici, teşvik edici, objektif, şeffaf, adil ve açık devleti vurgulamaktadır. Bu temel ögeler etrafında politikalarını ve kurumlarını yeniden düzenleyecek devlet, diasporanın gelişmesine de en büyük katkılardan birini vermiş olacaktır. Hatta bu sayede tözcü nedenlerle aşılması zaman alacak durumların yarattığ 1 kimi sorunlar da başkaca politikalar ve mekanizmalar yoluyla aşılabilir. Burada objektiflik, şeffaflık, adalet ve açıklık gibi temel ilkeleri gündeme getiren güdülenme, diasporanın mesken ülke içerisinde varacağ en gelişmiş noktanın ancak, yine diasporanın kendi doğal gelişimi ile ortaya konacak olmasıdır. Bu 'laissez faire' (bırakınız yapsınlar) anlayışından ziyade, sağlıklı ve güçlü bir diasporanın ortaya çıkabilmesinin en iyi yolunun, mesken ülkenin yaşam şartlarını birebir deneyimleyen, köken ülke ile bağları tarihselliği içerisinde değerlendirebilen ve mesken-köken dengesini en iyi yorumlayabilen unsur olarak diasporanın kendi kendisini inşasıdır. Oysa gelişimine müdahale edilmiş bir diasporanın tutum ve davranışlarının öngörülebilmesi veya eyleme geçmesindeki temel saikleri ile toplumsal yapısının gerçekliğinin objektif bir şekilde açıklanabilmesi çok da mümkün olmayacaktır. Dolayısıyla bu tür bir diaspora devlet açısından da planların ve stratejilerin gerçekleştirilmesinde güvenilir, güçlü bir 'partner' olmaktan uzak; öngörülemezliği nedeniyle güvenilmez, paradoksal bir araç haline gelecektir. 
Türkiye'de bugün iktidarda olan muhafazakâr anlayışın, tarihsel olarak modernizmin yerel pratiği olan Kemalizme karşıt olarak yapılanmış ve bu antagonizma içerisinde onunla eş-anlı ve karşıllklı etkileşim içerisinde biçimlenmiş olması onun da modernizmin ve Kemalizmin izlerini taşıyan bir muhteviyata sahip olmasını kaçınılmaz kılmaktadır (Mardin, 2006; Köker, 2013; Yaşl1, 2015; Yıldız, 2013). Bu düşünce temelde, Mardin'in (2006) ortaya koyduğu çevre-merkez denklemi çerçevesinde ortaya çıkan bir durumdur. Ayrıca yine buna ilaveten muhafazakâr anlayış Cumhuriyetle birlikte -siyasette zaman zaman iktidarda yer alsa da- öteki ve baskılanan olarak konumlandırılmış, dolayısıyla da baskı altında olan ötekinin sesi olarak sürekli iktidara yönelik olarak biçimlenmiştir. Fakat bugün eski öteki iktidardadır ve bu nedenle artık felsefi, entelektüel argümanları sinanmaktadır. Nitekim bize göre, bugünün Türkiye'sinde 'iktidarda' bulunan muhafazakârlığın en büyük sorunu da budur. Bugün iktidarda olan AK Parti, muhafazakâr düşüncenin tarihsel amaçları ve hedeflerinin gerçekleştiği başarı nesnesi olarak somutlaşmıştır. Bu açıdan muhafazakâr düşüncenin yeni konjonktür içerisinde temelini teşkil etmesi gereken felsefi-entelektüel havuz, nicelik ve nitelik bakımından son derece yetersiz politikleşmiş aydınlar (yani Sarıbay'ın deyimiyle sorgulayıp yeni bilgi üretmeyen ve yalnızca bilgi aktarımı yapan ve söylem üreten aydınlar) (Sarıbay, 2000, s. 147-149) veya etkinliği ve etkililiği yeterli olmayan çok az sayıdaki akademisyen tarafından doldurulmaktadır. Dolayısıyla bugün AK Parti politikaları ve icraatlarıyla muhafazakâr pratiğin, muhafazakâr felsefenin ve düşüncenin önüne geçtiği ters bir sürece işaret etmektedir. Tarihsel bağlamda ve uzun vadede pratiğin teorinin önünde gitmesi siyasi ve toplumsal alanın uzun süre kaldıramayacağı bir şeydir. Nitekim bu noktada AK Parti, yaşanan teorik yoksunluktan dolayı başlangıçtaki idealist çizgisinden giderek realist bir çizgiye kaymaya başlamış, var olan felsefi ve entelektüel eksikliğini eski Başbakan Davutoğlu'nun Stratejik Derinlik isimli kitabında ortaya konan vizyon ile doldurmaya çalışmıştır. Ancak, bu noktada post-modern, ulus-aşırı ve çok kutuplu bir dünyada modernist bir realizm projesi izlenimi doğuran Stratejik Vizyon Projesi, alı̧slageldik realist söyleme neo-muhafazakâr bir dinamizm kazandırmamasının yanında iktidarın ihtiyaç duyduğu felsefi/entelektüel yoksunluğun yerini doldurmaktan uzak görünmektedir.

Kitaptan çıkarsanan sonuca göre; diaspora fakat özellikle de kitaptaki kurguya istinaden Türkiye'nin tarihsel, mekânsal, ekonomik, kültürel nedenler dolasıyla 'Yakın Kıta Havzası' değerlendirmesine tabii kılınmış olan Avrupa Kıtası'nda yaşayan diaspora, Türkiye için güç dengelerindeki bir imkâna indirgenmektedir. Nitekim Davutoğlu (2001) bu noktayı kitabındaki en açık ifadelerle şu şekilde vurgulamaktadır: 
“Öte yandan, Batı ülkelerinde Müslüman azınlıkların lehine gözlenen demografik değişimden belki de en fazla etkilenecek ülkelerin başında Türkiye gelmektedir. Bu toplulukların Batı ülkelerinde artması kesin olan kültürel, siyasi ve ekonomik etkilerinin değerlendirilmesi bu ülkelerde önemli bir insan unsuru barındıran Türkiye için iyi değerlendirilmesi halinde büyük bir imkân iken iyi değerlendirilememesi durumunda her an karşı etki doğurabilecek potansiyel bir güçtür, Türkiye bu demografik değişim unsurları ile yabancılaşmayan bir tavır geliştirerek hem kültürel hem de siyasal alanda ciddi bir temsil kabiliyeti kazanabilir." (s. 225)

İktidarın yaşadığı ontolojik sıkıntı, piyasa aktörlerinin de etkilemesiyle, son derece pragmatik bir bağlam yaratarak diasporayı kontrol edilebilir bir yapının dizaynına yönelik hedeflerin kapsamına itmektedir. Zira 'eskiyi' sonlandırmak ve/ veya 'restorasyon' yapmak iddiasında olan iktidarın dağarcığında yeni bir felsefi temel, yeni bir teorik zemin bulunmamaktadır. Dolayısıyla benimsenmiş olan bu kontrolcü-tahakkümcü çizgi, lobicilik çizgisine yakın bir çizgidir ve gerçekten de piyasa tarafından destek görmektedir. Piyasa, diasporanın sahip olduğu bağlantıların devlet tarafından desteklenmesi ve güçlendirilmesi ile daha fazla pazar yaratmak, daha fazla iş fırsatı yakalamak itkisiyle hareket etmektedir ve bu, alışıldık iktidar ilişkilerinin devamını sağlayacağından oldukça avantajlıdır. Söz konusu durum, devletin inşasındaki sermaye ile olan bağlara ışık tutmasının yanında, otoriter devletin hedefleriyle de uyum sağlamaktadır. Bu nedenle diasporayı lobicilik ekseninde gören tüm yaklaşımlarda oportünist ve biçimlendirici tutumlar egemendir ve diasporanın varoluşsal nitelikteki en temel toplumsal-siyasi-kültürel bağlamları ikinci ve üçüncü plana atılmaktadır. Diasporanın bu trendi en az kayıpla atlatmasının yolu, devletin kendi uzun vadeli menfaatleri için diasporanın neliğine ve nasıllığına 1şık tutacak bilimsel ve objektif bir çalışma başlatmasıdır. Zira bir yaklaşım tarzı benimsemek ve politikalar oluşturmak noktasında farklı çıkar ilişkileri, partizanlık, devletçilik gibi güdüler nedeniyle manipüle edilmiş verileri esas almak, devletin üzerinde durduğu zeminin de kaymasına yol açacaktır.

\section{Diaspora Politikalarına İlişkin Temel Öneriler}

Buraya kadar anlatılanlar ışığında sağlıklı bir diasporizasyonu mümkün kılabilmek için en temel adımların devletin demokratikleşmeye olarak atacağı adımlar olduğu açıktır. Fakat bununla birlikte sağlıklı bir diasporizasyona katkı sağlamak için devletin diasporaya yönelik demokratikleşme dışında da atabileceği bir takım adımlar, değiştirmesi gereken bazı politikalar, politikalar bulunmaktadır. Diaporizasyonun demokratikleşme ile olan eşanlılı̆̆ ve diasporizasyon konusunda yaşanan sıkıntılar dikkate alınarak, pratik ve politika bağlamında şu öneriler getirilebilir: 
1- Türkiye'nin devlet olarak diasporaya ilişkin ivedilikle ele alması gereken ilk nokta; diasporanın neliğine ve nasıllığına ilişkindir. Önceki başlıklarda açımlamaya çalıştığımız üzere Türkiye'nin diasporaya bakışı ve yaklaşımları temelde iki ana koldan beslenmektedir. Bunlardan ilki, 'devlet aklı' olgusu çerçevesinde ortaya çıkan kontrol edilebilir, araçsallaştırılmış, tözcü ve kapalı bir yapıya işaret eden, göçmenlik kavramını aşamamış klasik diaspora anlayışı; ikincisi ise, üretim ve finans güçlerince manipüle edilen ve lobicilik ile diasporayı aynılaştırarak sunan pragmatik hatta bazı örneklerinde oportünist anlayıştır. Bu bakımdan Türkiye Devleti acilen, diasporayı klasik ve modern bakış açılarının farklarını yansıtacak biçimde açımlayabilecek, diaspora konusunda bir yaklaşım, genel bir politik çizgi belirlenmesine kaynaklık edebilecek yeterlilikte bir çalışma hazırlatmalıdır.

2- İkinci önerimiz devletin ilgili tüm birimlerinin yetkili kişilerini, diaspora konusunda devlet adına çalışanları objektif ve dürüst çalışma konusunda uyarmalı, teşvik etmelidir. Zira çalışanların partizanlık, devletçilik ve sair nedenlerle oto-sansür uygulaması, verileri manipüle etmesi, çalışmalarında gerçek sonuçları ve yorumları ortaya koymaktan imtina etmeleri devlet olarak Türkiye'nin diasporayı olduğundan daha da yanlış değerlendirmesine ve tamamen kaybetmesine yol açmakadır. Dolayısıyla devletin doğru bir yaklaşım benimseyebilmesi ve doğru bir politika ortaya koyabilmesinin yegâne yolu, hoşa giden yahut gitmeyen gerçek verilere ve analizlere muhtaç olduğundan, gerçeklerin gözardı veya örtbas edilmeyeceği bir çalışma iklimi sağlanması şarttır. Ayrıca yine kurumsal-kişisel ego çatışmaları yaşanmaması, çalışma verimliliği sağlanması ve güvenilir sonuçlar elde edilebilmesi için dikeyden ziyade yatay örgütlenme biçimleri tercih edilmeli (nitekim YTB örneğindeki gibi örgütlenme modelleri merkezin hiyerarşisini ve otoritesini yerleştiren, kurumlar içerisinde kişileri güçlendiren ve öndeleyen dikey modellerdir), liyakat esas olmalı, mümkün olduğunca merkezin ve bürokratik hiyerarşinin diasporik çalışmaların kurumsal sınırlarını aşındırması önlenmelidir.

3- Üçüncü öneri olarak Türkiye'nin yurt dışı misyonlarındaki görevlilerinin niteliklerini ve niceliklerini artırması, yeni politikaları ve planları doğrultusunda ihtiyaca göre yeni birimler oluşturması, kültürel ve düşünsel propagandanın yanı sıra diaspora ile etkileşimi de kuvvetlendirecek kurumlar, ofisler-irtibat noktaları, mekanizmalar dizayn etmesi gerekmektedir denebilir. Şu an için diasporaya propaganda sekreterliği gibi çalışan YTB ve Yunus Emre Kültür Enstitüleri yeniden belirlenecek politikalar bağlamında yukarıda belirtilenler gibisinden oluşumlara örnek teşkil edebilir.

4- Dördüncü adım olarak ise Türkiye'nin, diasporik etkinliğin ve/veya etkililiğin yüksek olduğu ülkelerdeki akademilerde Türkiye araştırmaları ve Türk Dili üzerine kürsüler kurulması, bölümler, programlar ve dersler açılması araştırma- 
lar yapılması için politik, bürokratik ve akademik kanallarını devreye sokması; söz konusu ülkenin entelejansiyasının Türkiye ve diaspora temalı çalışmalar yapması için teşvik faaliyetlerinde bulunması; sergi, festival, panayır, sempozyum, seminer, konferans gibi etkinlikler organize etmesi veya edenlere destek olması; sinema, resim, fotoğraf, kitap, dergi, rapor vb. sanatsal ve düşünsel çalışmalara destek vermesi, organize etmesi; ödüller ve yarışmalar düzenlemesi; özel günler, kokteyller tertip etmesi; sosyal akışın yoğun olduğu kamusal mekânlara görünürlüğü olan ve Türkiye ve diasporasına yönelik olumlu düşünce ve hisler geliştirilmesini sağlayacak eserler kazandırması, ilanlar ve reklamlar koydurması; gerekirse tüm bunlar için fonlar oluşturması ve finansal kaynak yaratması, hedefteki mesken ülkenin sanatsal, düşünsel ve kamusal yaşamına yönelik görünürlüğü olan, farkındalık ve fark yaratabilecek faaliyetlerde bulunmalıdır denebilir.

5- Beşinci olarak, doğrudan diasporik faaliyetlerin, derneklerin, örgütlerin, kişilerin kendilerine ya da diasporaya ve devletin diaspora politikalarına katkı ve destek sağlayan kişi veya oluşumlara finansal ve manevi bakımlardan destek sağlaması gereği sayılabilir. Ancak, her türlü devlet biriminin söz konusu kapsam dâhilinde gerçekleştireceği finansal ve/veya manevi destekler şeffaf, normlara dayalı, kolay ulaşılabilir ve araştırılabilir olmalıdır.

6- Altıncı olarak ise, bir önceki öneri ile ilişkili olarak, yurtdışındaki saygın üniversitelerde diaspora konusunda öğrenim görmek isteyenlere veya yine bu kabilden üniversitelerde ya da ülkelerde diaspora alanında araştırma yapmak isteyenlere burs ve kredi olanakları yaratılması, yanı sıra Türkiye'de de (Oxford Üniversitesi'nde olduğu gibi) göç çalışmalarında olduğu gibi ve fakat kesinlikle göçten ayrı, alanında önemli bilim insanlarını bünyesinde toparlayabilecek bir veya birkaç bölüm ya da en azından ileri gelen üniversitelerde yüksek lisans-doktora düzeyinde program açılması gerekmektedir. Öte yandan açılacak bölümlerin veya programların teşvik edici burs, araştırma ve kariyer olanakları sunması, yalnızca Türk diasporasına yönelik araştırmalarla sınırlı kalmaması, çağın bilimsel koşullarına ve gereklerine uygun interdisipliner bir eğitim felsefesi ve yöntemi benimsenmesi de Türkiye'nin diaspora araştırmaları ve devlet politikaları açısından önemlidir.

7- Yedinci önerimiz, devletin diasporaya ilişkin politika ve faaliyetlerinin objektif, adil ve şeffaf olmasıdır. Bu üç kriter devletin (devlet yönetiminde tutarlılık ve devamlılık prensibi gereği) hükümetlerle birlikte değişmeyecek mantıklı ve kabul edilebilir bir çizgi izlemesi, demokratikleşmesi ve aynı zamanda da diaspora ile sağlıklı bir etkileşim kurabilmesi açısından oldukça önemlidir.

8- Sekizinci önerimiz, devletin diaspora üzerindeki yarım asırlık tahakkümünden vazgeçilmesidir. Türkiye'nin diaspora fakat özellikle de Avrupa diasporası üzerinde yarattığı angajman ve otorite, diasporanın gelişimini son derece olumsuz 
etkilemektedir. Devlet yönlü rüzgarların etkisi ile biçimlenen diaspora, modern bir çizgiye oturma arzu ve hevesi gösterse de pek çok noktada devletin belirlenimleri ve stratejilerinin dışına çıkmakta zorlanmaktadır. Bu noktada bilhassa entelektüel çekirdeği oluşturan kesimlerle yaşanan ihtilaflar ve pek çok kesimin diaspora kapsamı içerisinde kıymetlendirilmemesi de diasporaya zarar vermektedir.

9- Dokuzuncu olarak bir önceki madde ile ilişkili biçimde, devletin, Diyanet İşleri, DTİB-Diyanet Vakıfları, YTB, ataşelikler, müşavirlikler gibisinden toplumsal yapıyı biçimlendirmeye, kategorize etmeye, katmanlaştırmaya ve dikeyleştirmeye yarayan araçlarının bir kısmını yeniden programlaması, bir kısmını ise alandan tamamen çekmesi gerekmektedir. Bu doğrultuda bilhassa kültürel ve toplumsal yaşama yönelik etkileri olan kurumların Ankara merkezli politikaların pedagojisini ve manipülasyonunu yapmayı acilen bırakması gerekmektedir.

10- Onuncu önerimiz, YTB bünyesinde oluşturulan danışma kurullarının, devlet aklının ve devlet iktidarının yeni bölüşüm içerisinde de korunmasına hizmet ettiğinden, kaldırılmasıdır. Diaspora içerisinden ve devlet içerisindeki kurumlardan gelen insanların aynı masa etrafında bir fikir teatisine girmesi, uzlaşma araması veya politika ve stratejiler belirlemesi, çok sempatik gelmesine karşın aslında, devletin dolaylı yollardan diaspora için liderlik tayin etme ve tayin edilmiş liderler aracılığı ile de diasporayı kontrol altında tutma arayışı olarak değerlendirilmelidir. Dolayısıyla YTB bünyesindeki albenisi olan danışma kurulları vb. de esasen diasporayı içten içe kemirmekten ve onun özgünlüğünü, kendi gelişim çizgisini ve kendi belirlenimlerini sekteye uğratmaktan öte bir işleve sahip olmayacak, devletin panopticon ${ }^{2}$ mimarisini diasporik düzlemdeki yeni paylaşım kavgasına taşıyacaktır.

11- On birinci olarak, yetki çakışması sorununa çözüm getirilmesi gereği ifade edilebilir. Yurt dışında görev ve sorumluluk alan, YTB, Yunus Emre Kültür Enstitüleri gibi kurumlar kendi özgün kararlarını vermek, politikalar oluşturmak, planlar yapmak noktasında Ankara'ya göbeğinden bağlı durumdadır. Aldıkları kararlar ve faaliyetler zaten hiçbir şekilde Ankara'nın tezlerine ve bakış açlarına aykırı olamayacağı gibi, Ankara'dan onay almadan harekete geçme şansları da yoktur. Yurtdışı odaklı faaliyet gösteren birimler bu konuda oldukça dertlidir. Nitekim bu konuda son olarak Berlin Yunus Emre Enstitüsü’nün yeni başkanı Prof. Dr. Faruk Akyol, Radikal Gazetesi'nden Müge Akgün'le yaptığı ropörtajda bu konuya açıcça değinmektedir (Akyol'dan akt. Akgün, 2014). Gerek Kültür Bakanlığı, gerek Dışişleri Ba-

2 İngiliz filozof Jeremy Bentham'ın 1875 yılında tasarladığı ve hiç hayata geçirilmemiş olan bir hapishane tasarımıdır. Bu tasarımda ortadaki gözetleme kulesinin karanlıkta kalarak görünmez kılınmasıyla etrafını çevreleyen hücrelerdeki mahkumlar üzerinde her daim gözetlendikleri duygusu yaratılmak böylece bir oto-kontrol ortaya çıkartılmak amaçlanmıştır. Foucault bu tasarımı asimetrik iktidar ilişkilerini açıklamak için kullanmıştır. 
kanlığı, gerek Çalışma Bakanlığı, gerek Aile ve Sosyal Politikalar Bakanlığı vd. yurt dışı odaklı olarak görev yapan kurum ve kuruluşların kendi özgür politikalarını ve planlarını ortaya koymasına müsaade etmemektedir. Bu noktada sikıntının ana kaynağı, Ankara'nın otoritesini paylaşmak istememesi ve kendi belirlediği çizginin harfiyen uygulanması arzusu doğrultusunda yaşadığı güvensizliktir.

Buraya kadar saydığımız on bir madde, bizim çalışmamız neticesinde parmak basmak istediğimiz temel noktaları ortaya koymaktadır. Yaptığımız tespitler ve getirdiğimiz öneriler, çalışmamızın izleği ve ruhu bağlamındaki ana hususlara odaklanmakta, teorik düzeydeki temel sorunlara sşık tutmakta, alt-yapının önemine vurgu yapmaktadır. Çalışmamız devlet politikalarını mesele edinmesinden dolayı tespit ve önerilerimiz devlete yönelik bir değerlendirme çerçevesiyle sınırlandırılmıştır.

\section{Sonuç}

Sonuç olarak, tüm açıklananlar ışığında, diasporizasyon sürecinin devlet tarafından yanlış anlaşıldığı ifade edilebilir. Zira Türkiye açısından diaspora bir koz, bir araç ve/veya bir çeşit etki ajanı olarak değerlendirilmektedir. Oysa çalışmamızın temel bakış açısını oluşturan modern diaspora yaklaşımları bunun tam tersi bir izlek çizmektedir.

Bu bağlamda Türkiye'nin diaspora algısında ve mevcut politikalarında belirginleşen birkaç temel dayanak noktası, birkaç yöntem, düzlem ve refleks bulunduğu gözlemlenmektedir. Bu bakımdan Türkiye'nin toplumsalı sindirmek üzerine kurgulanmış otoriter devlet anlayışının diaspora konusuna da kendi demokrasi sorunsalının sınırları çerçevesince yaklaştığı, tahakkümcü bir merkez etrafında, memur bir diasporik yapı inşa etmeye çalıştığı görülmektedir. Bu bağlamda Türkiye Devleti'nin kimi uygulamaları, hedefleri ve görünümleriyle modern diasporayı çağrıştırsa da esas itibarıyla tözcü ve klasik bir diaspora anlayışında 1srar ettiği söylenebilir. Ancak, elbette ki diaspora toplumsal bir oluşum, organik bir yapı olduğundan değişimlerden etkilenmemesi ve devletin otoritesini sorgulanır kılan bir iklime ulaşmaması mümkün değildir. Bu değişim ve dönüşüm, bir bakıma devlet için de elzemdir. Zira ulus-aşırılaşma ve küreselleşmenin artan etkisi ve diasporizasyonun toplumsalın tanımına getirdiği yeni yorum ve vizyon, devletin de ontolojik menfaatleri açısından icabet etmesi gereken bir akış yaratmaktadır. Bu bağlamda modern karakterli bir Türk diasporasının inşası için devletin bazı hasletlerini ve politikalarını gözden geçirmesi, yeni bir başlangıç yapması gerektiği söylenebilir. Bu açıdan çalışmamız, günümüzde yanlış anlaşıldığı açık olan diaspora konusunu açımlamak ve Türkiye'nin pratikteki yanlışlıklarını tespit ederek devlet odaklı bir takım öneriler getirmek istemektedir. 


\title{
Diaspora Concept and a Socio-Political Analysis of Turkey's Diaspora Politics in the Context of Modern Theory
}

\author{
Ergin Ulusoy
}

Diaspora is one of the most importent social and political facts of our time. People's mobility between countries has begun to affect almost every field on the national and global levels, like economics, society and politics. This became especially true after modernism and nation-states took center stage, along with the territorial use of national sovereignty and the legal and political frameworks of international relations. Diaspora eventually began to stand out as the term given to the accumulation of large numbers of immigrants who were living outside of their homelands.

In this context, our study primarily makes a theoretical explonation of diaspora and then analyses the historical determinations underlying Turkey's diaspora politics in the context of modern approaches and within a political-sociological framework. The article's scope is defined as diaspora theory, globalization, the nation-state, nationalism, citizenship, integration and Turkey's political-social history. The first topic, "The Conceptual Dimension of Diaspora and Classical and Modern Diaspora Approaches," examines the diaspora concept, as well as its etymological roots and theoretical content.

One can see diaspora's root words in ancient Greek civilization, for it is a combination of dia ("with" and "resultant") and speiro ("spread") and was used to "describe the migration or colonization of people from a metropolis" (Cohen, 1997, p. ix). On the other hand, the concept experienced a significant change after th e Romans drove the Jews out of Jerusalem, namely, communuties that emmigrated 
involuntarily after the imposition of a second force or conditions on the territories seen as their homelands. In particular, it gained a trait for the peoples who were driven during World War II.Nevertheless, "a very short time ago, this concept was used mostly to express the post-exile disbandment of Jews, even though there were records of very large Armenian, Greek and African Diasporas" (Butler, 2001, p. 190-192), which had been the case until the begining of globalization. However, the feminist perspective has criticized this term on the grounds that the Greek word for "sperm" is a gender-specific and masculine concept and thus led to gender-specific definitions/determinations: "Others who equal diaspora ethnicity claim that the diaspora is a masculine-specific concept" (Alinia, 2007, p. 32).

There are two mainstreams in diaspora theory: the classical and the modern approach. The first one can be explained more as an institutionalized form of a developed tradition on the outlines given above. According to this, the traditional perception of diaspora and the integration of all kinds of values, judgments, events, pieces and so on feed this perception as an identity and social norm. The tragic events that took place at the beginning of the classical interpretation, as well as the longing and rejoicing hopes felt for the motherland, are perceived as the two most important founding elements: "Diaspora implies some cultural differences between the diaspora and the other groups in the direction of their old conception" (Faist, 2010, p.15 from Beck) Again in this respect, the diaspora's "old conceptions implies that the members are not socially (i.e., politically, economically and culturally) fully integrated into the host countries, they impose boundaries between the majority groups and protect those borders. This concept of diaspora is often associated with a border guard regarding the discrimination that a dominant majority applies to diasporic groups" (Faist, 2010, p.13 from Bhabha).

The modern approach is a comment, as it always implied, that saves the diaspora from the conceptual framework built by tradition and redefines the requirements and realities of the age. In a modern diaspora, the individual is in the center. The diaspora, as a community, is based on a network-like structure that comes to life with globalization and transnationalism, instead of a community structure dictated by traditional values. Liberal values are more evident because the "community" is not blessed in modern diasporas. Thus, "the permeable and ever-transforming social and cultural formations of modern diasporas, which have a very different, mixed and heterogeneous identity than the unity of the intact, compulsorily or forcedly displaced persons in search of a homeland of the sacred tribal community" (Ataman, 2012, p.53, from Georgiou) are alleged to be born again. 
On the other hand, whether considered in the context of the classical approach, modernization affects and continually shapes the diaspora and the globalization that fosters concepts such as liberalism, democracy, people and freedoms, as well as market liberty, that seem to dominate today. In a world based on nation-states and international order, immigration is one of the most important factors that can shake a state's sovereignty. The fact that immigration takes place on a very large scale toward the developed countries and the utilization of the immigrants' predecessors, who have previously entered and settled in those countries, is forcing all sorts of national and international institutionalizations. Every migration does not have to result in a diaspora; however, every one that occurs in relation to diasporas is important in terms of being able to control migration and to be more organized. The final migration within the diaspora gives people the chance to survive and even adapt to a new society - a realistic hope, a chance for a new life.

The second topic of this study, the "Analysis of Turkey's Diaspora Politics in the Context of Modern Approaches," explains and evaluates the politics of its current diasporas that are in the process of formation, the historicalities underlying these politics as well as the bases and changes in the post-AKP politics.

As shown in the previous section, Turkey has approached the topic as an immigration issue, especially as it became familiar during the 2000s. Therefore, it has shaped the relevant plans and programs according to the requirements observed on the scene, the diversion of different groups of pressures and the very political-cultural determinations of everyone. On the other hand, there are traces of Kemalist, militarist, centralized and otherizing state policies in Turkey's diaspora policies. In this sense, a total of five areas, three of which are based on the formation of policies and put forward by Erdogan, and two of which are put forward by this work: the fields of education, religion, work, economy and non-governmental organisations (NGOs), respectively. All of these policies have points in common, such as the state's apparent desire to protect its diaspora against assimilation. However, when analysed, one can see that the state's anti-assimilationist policies have sought to influence and dominate the diaspora, which, in part, has caused serious damage to diasporan adaptations to the home country and diverted the diasporisation process from its natural course.

It seems that Turkey has always come close to viewing the diaspora with suspicion, and yet expects its members to serve as influetial agents in the host-countries. In particular, the diaspora is always expected to devote itself to lobbying and economic and ideological transfers toward Turkey. Thus, one can say that Turkey's 
policies are mainly based on those patterns associated with the classical approach, although the expectations are more modern.

As the people living abroad began to progress in class-status maintenance within the residential community structure and economy, a strand of migration from immigration to diasporalization began to take place in the office of Turks Abroad. Turkey has responded to the change and has taken action to revise its policies in the framework of the newly evolving situation. At this point, the AK Party's ideology best knows the situation and problems of the diaspora in terms of its historical and social roots. With the advent of power, the importance of the EU process and external relations was increasingly emphasized during a relatively short period of time, and the issue of diaspora began to be appreciated. As a result, a diaspora-related institution was established under the name of "Presidency of Turks Abroad." This has been the most important step in the sense that the state's view of the issue has been officially institutionalized.

During the AK Party's first two years in power, the issue of diaspora remained on the agenda, trying to meet the demands of long-standing problems. However, especially in recent years, this issue has been reduced to a foreign policy and economic financing tool parallel to the ideas of former Prime Minister Davutoglu's book Strategic Depth (2001). Thus, the state pressure on the diaspora has increased instead of being reduced, and the deepening polarizations within Turkey have also been shattered abroad. Therefore, since the relationship between the state and the diaspora is related to democratic development in Turkey, the old state approaches have been revived and the authority of a dominant center has begun to be felt on the diaspora once again. Diasporas, therefore, have resumed their political and social life in the host countries.

The last issue of our work offers some feasible recommendations for these problems. When considering the Turkish diaspora, it is clearly more important for the state to have a disproportionate influence and sanction power in terms of the results of the relationship. In this context, the proposals explained under the eleven articles can be said to focus on what Turkey needs to do when it is considered that the work centered on state policies.

This study used both local and foreign sources. In this sense, although the subject's theoretical dimension is explained, it has tried to utilize different domestic and foreign names in the sections that focus on Turkey. These resources can be listed as follows: 


\section{Kaynakça | References}

Akgün, M. (2014, 28 Ağustos). Almanya'daki Ü̧̧ Milyon Türkiye Kökenlinin Bir Münevver Kesimi Yok [Faruk Akyol ile Yapılan Ropörtaj]. Radikal: http://www.radikal.com.tr/yazarlar/muge_akgun/almanyadaki_uc_milyon_turkiye_kokenlinin_ bir_munevver_kesimi_yok-1209380 adresinden 28 Ağustos 2014 tarihinde edinilmiştir.

Alinia, M. (2007). Diaspora Mekanları: Kürt kimlikleri Öteki Olma Deneyimleri ve Aidiyet Politikaları. (F. Adsay, Çev.) İstanbul: Avesta Yayınları.

Artukoğlu, O. S. (2005). Yurt Dışı İş̧̧ Tasarruflarının Türkiye Cumhuriyet Merkez Bankası. Banka Sistemi ve Türkiye ekonomisi Üzerine Etkileri [Uzmanlık Yeterlilik Tezi]. Ankara: Türkiye Cumhuriyet Merkez Bankası İşçi Dövizleri Genel Müdürlüğü.

Ataman, B. (2012). Kozmopolitan Hayatlar-Diasporik Kimlikler. İstanbul: Libra Kitapçllı ve Yayıncılık.

Baştürk, E. (2011). Demokratik Devletin Gerekleri ve Türkiye. Liberal Düşünce Dergisi, (61-62), 49-61.

Belge, M. (2012). Militarist Modernleşme: Almanya-Japonya-Türkiye. İstanbul: İletişim Yayınları.

Butler, K. (2001, 2 Ekim). Defining Diaspora: Refining A Discourse. Diaspora: A Journal of Transnational Studies, 10(2), 189219. http://sites.middlebury.edu/nydiasporaworkshop/files/2011/04/Defining-Diaspora1.pdf adresinden 16 Mart 2011 tarihinde edinilmiştir.

Cohen, R. (1997). Global Diasporas: An Introduction. London: UCL Press.

Cumhuriyet Gazetesi. (2013). Ekmek ve İslam kavgast. http://www.cumhuriyet.com.tr/haber/diger/438652/Ekmek_ve_islam_kavgasi.html adresinden 18 Şubat 2017 tarihinde edinilmiştir.

Davutoğlu, A. (2001). Stratejik Derinlik/Türkiye’nin Uluslararası Konumu. Küre Yayınları: İstanbul.

Erdoğan, M. (2014, 9 Nisan). Türk Diasporası ve Türkiye devletinin diaspora politikaları [Kişisel mülakat].

Faist, T. (2010). Diaspora and transnationalism: What Kind of Dance Partners? R. Bauböck, T. Faist (Ed.), Diaspora and Transnationalism: Concepts, Theories and Methods içinde (s. 9-35). Amsterdam: Amsterdam University Press.

Görmezöz, G. (2011). Uluslararası Göç ve Tarihsel Gelişimi. Geniş Açı Dergisi, (3), 38-44. Ankara: Türkiye İş Kurumu Genel Müdürlüğü.

Güngör, V. (2005). Bizimkilerin Pedagojisi: Göç-Kültür-Kimlik ve Hollandalı Türkler. Ankara: Liman Kitapları.

Gür, M. (2012). Avrupa'da İslamcı Örgütler. İstanbul: Evrensel Basım Yayın.

II. Beş Yıllık Kalkınma Planı. (1968). T.C. Başbakanlik Devlet Planlama Teşkilati Müsteşarlığı: http://www.kalkinma.gov.tr/ Lists/Kalknma\%20Planlar/Attachments/8/plan2.pdf adresinden 11 Aralık 2013 tarihinde edinilmiştir.

İçduygu, A. (2006). Avrupa Birliği İlişkileri Bağlamında Uluslararası Göç Tartışmaları. İstanbul: TÜSİAD.

İçduygu, A. (2012). Kentler ve Göç: Türkiye-İtalya-İspanya örnekleri. İstanbul: Bilgi Üniversitesi Yayınları.

Karcı Kofralı, D., Üstübici, A., De Clerck, H. (2010). “Turkey Country and Research Areas Report”. EUMAGINE: http://www. eumagine.org/outputs/PP5\%20-\%20Turkey\%20Country\%20and\%20Research\%20Areas\%20Report\%20-\%20Final. pdf adresinden 24 Şubat 2011 tarihinde edinilmiştir.

Köker, L. (2013). Modernleşme Kemalizm ve Demokrasi. İstanbul: İletişim Yayınları.

Laguerre, M. S. (2006). Diaspora-Politics and Globalization. A.B.D., New York: Palgrave Macmillan.

Mardin, Ş. (2015). Türkiye'de Toplum ve Siyaset. İstanbul: İletişim Yayınları.

Reis, M. (2004). Theorizing Diaspora: Perspectives on "Classical” and "Contemporary" Diaspora. IOM International Migration, (42), 41-60. http://www.polsci.chula.ac.th/jakkrit/anthro/Borderland_files/Theorizing\%20Diaspora.pdf adresinden 24 Şubat 2012 tarihinde edinilmiştir.

Sarıbay, A. Y. (2000). Kamusal Alan, Diyalojik Demokrasi, Sivil İtiraz. İstanbul: Alfa Basım Yayım Dağıtım.

Şenay, B. (2012). Trans-Kemalism: The Politics Of The Turkish State In The Diaspora. Ethnic And Racial Studies, 35(9), 16151633.

Tanör, B.; Boratav, K.; Akşin, S. (2005). Türkiye Tarihi 5: Bugünkü Türkiye 1980-2003. İstanbul: Cem Yayınevi.

Tölölyan, K. (2012, Nisan). Diaspora studies: Past, Present and Promise. Internaional Migration Institute/University of Oxford/Diasporas Programme, Working Papers-Paper 55.

Turkishnews. (2008). Alman savc1: Türk Hükümeti Baskı Yaptı. https://www.turkishnews.com/tr/content/2008/09/06/deniz-feneri-alman-savci-turk-hukumeti-baski-yapti/ adresinden 16 Şubat 2017 tarihinde edinilmiştir.

Yaşlı, F. (2015). Vesayete Karşı Demokrasi: Yeni Rejimin Kurucu Ötekisi Olarak Kemalizm. İ. Parlak (Ed.), Ötekinin Var Olma Sancıs: Türk Politik Kültüründe Şeytanlaştırma Eğilimleri içinde (s. 437-483). Bursa: Dora Basım-Yayın-Dağıtım.

Yıldız, A. (2013). Ne Mutlu Türküm Diyebilene: Türk Ulusal Kimliğinin Etno-Seküler Sinırlan 1919-1938. İstanbul: İletişim Yayınları.

Zürcher, E. J. (2010). Modernleşen Türkiyénin Tarihi. (Y. S. Gönen, Çev.) İstanbul: İletişim Yayınları. 